\title{
ORGANIC MATERIAL DECOMPOSITION AND NUTRIENT DYNAMICS IN A MULCH SYSTEM ENRICHED WITH LEGUMINOUS TREES IN THE AMAZON ${ }^{(1)}$
}

\author{
José Henrique Cattanio ${ }^{(2)}$, Ronald Kuehne ${ }^{(3)} \&$ Paul L.G. Vlek $^{(4)}$
}

\begin{abstract}
SUMMARY
The new techniques proposed for agriculture in the Amazon region include rotational fallow systems enriched with leguminous trees and the replacement of biomass burning by mulching. Decomposition and nutrient release from mulch were studied using fine-mesh litterbags with five different leguminous species and the natural fallow vegetation as control. Samples from each treatment were analyzed for total $\mathrm{C}, \mathrm{N}, \mathrm{P}, \mathrm{K}, \mathrm{Ca}, \mathrm{Mg}$, lignin, cellulose content and soluble polyphenol at different sampling times over the course of one year. The decomposition rate constant varied with species and time. Weight loss from the decomposed litter bag material after 96 days was $30.1 \%$ for Acacia angustissima, $32.7 \%$ for Sclerolobium paniculatum, $33.9 \%$ for Iinga edulis and the Fallow vegetation, $45.2 \%$ for Acacia mangium and $63.6 \%$ for Clitoria racemosa. Immobilization of $\mathrm{N}$ and $\mathrm{P}$ was observed in all studied treatments. Nitrogen mineralization was negatively correlated with phenol, C-to-N ratio, lignin + phenol/N ratio, and phenol/phosphorus ratios and with $\mathrm{N}$ content in the litterbag material. After 362 days of field incubation, an average (of all treatments), $3.3 \% \mathrm{~K}, 32.2 \% \mathrm{Ca}$ and $22.4 \% \mathrm{Mg}$ remained in the mulch. Results confirm that low quality and high amount of organic $\mathrm{C}$ as mulch application are limiting for the quantity of energy available for microorganisms and increase the nutrient immobilization for biomass decomposition, which results in competition for nutrients with the crop plants.
\end{abstract}

Index terms: contrasting chemical compositions, nutrient mineralization; nutrient immobilization; litterbags.

\footnotetext{
(1) Recebido para publicação em março de 2006 e aprovado em fevereiro de 2008.

(2) Professor da Faculdade de Meteorologia, Universidade Federal do Pará - UFPA. Campus Universitário do Guamá, Rua Augusto Corrêa 1, Instituto de Geociências - Campus Básico, CEP 66075-110 Belém (PA). E-mail: cattanio@ufpa.br

${ }^{(3)}$ Colaborador do Institute of Agriculture in the Tropics (IAT), University of Goettingen, Grisebachstr. 6, 37077 Goettingen, Alemanha. E-mail: rkuehne@gwdg.de

(4) Professor do Center for Development Research (ZEF), Walter Flex Str. 3, 53113 Bonn, Alemanha. E-mail: pvlek@uni.bonn
} 


\title{
RESUMO: DECOMPOSIÇÃO DE MATERIAL ORGÂNICO E DINÂMICA DE NUTRIENTES EM UM SISTEMA DE COBERTURA MORTA ENRIQUECIDO COMÁRVORES LEGUMINOSAS NA AMAZÔNIA
}

\begin{abstract}
As novas técnicas propostas para a agricultura na Amazônia incluem sistema de rotação de capoeira enriquecido com árvores leguminosas e transformando a queima da biomassa em cobertura morta sobre o solo. A decomposição e a liberação de nutrientes da cobertura morta foram estudadas usando sacos de liteira com malha fina que continham cinco tratamentos com diferentes espécies de leguminosas em comparação a um tratamentocontrole com vegetação natural. As amostras para cada tratamento foram analisadas para conteúdos de C total, $N, P, K, C a, M g$, lignina, celulose e polifenóis solúveis em diferentes tempos de amostragem durante um ano. A razão constante de decomposição variou com a espécie e com o tempo. A perda de massa nos sacos de decomposição foi de $30,1 \%$ para Acacia angustissima, de $32,7 \%$ para Sclerolobium paniculatum, de 33,9\% para Inga edulis e para a vegetação secundária, de 45,2\% para Acacia mangium e de $63,6 \%$ para Clitoria racemosa. Foi observada imobilização de $N$ e $P$ em todos os tratamentos, sendo a mineralização do $N$ negativamente correlacionada com o fenol, razão $C / N$, razão (lignina + fenol)/N, razão fenol/P e o conteúdo de $N$ nos sacos de liteira. Depois de 362 dias de incubação no campo, 3,3\% de K, 32,2 \% de Ca e 22,4\% de $\mathrm{Mg}$ permaneceram no material em decomposição. Os resultados evidenciaram que a baixa qualidade mineral e a alta quantidade de carbono orgânico e aplicado como cobertura morta podem limitar a quantidade de energia disponível para os microrganismos resultando em uma competição por nutrientes com as plantas agrícolas.
\end{abstract}

Termos de indexação: composição química contrastantes, mineralização de nutrientes, imobilização de nutrientes, sacos de liteira.

\section{INTRODUCTION}

Fallow vegetation plays an important role in maintaining or restoring soil productivity in the slashand-burn agriculture system of the Amazon basin. However, the intensification of land use has drastically reduced the fallow period. Therefore, the soil quality has to be restored in a shorter time period. This could be accomplished by the introduction of intensified forms of fallow management such as planted or enriched fallow systems (Brienza Jr., 1999), which are modifications of the slash-and-mulch systems.

For research in applied soil biology, the synchronization of nutrient release from organic material and the plant nutrient uptake are a topic of great interest in cases where burning is replaced by biomass mulching, (Addiscott et al., 1991; Myers et al., 1994). Furthermore, the existence and extent of plant-microbe competition for inorganic and organic $\mathrm{N}$ and $\mathrm{P}$ resources need to be elucidated (Kaye \& Hart, 1997). Crop yields in the project area (Eastern Amazon, Brazil) following slash-and-mulch fall short of those after burning, which is ascribed to a lack of nutrients (Denich et al., 2004). In order to project more efficient agricultural systems, there should be a clear understanding of the determinants of nutrient supply, especially those that condition nutrient release from plant residues (Seneviratne, 2000).
Organic resources play an essential role in soil fertility management in the tropics by their shortterm effects on nutrient supply and longer-term contribution to soil organic matter (SOM) formation (Palm et al., 2001). The decomposition rate and the amount of nutrient release from organic matter (OM), particularly from leguminous trees, determine the short-term benefits of tree residues for crop nutrition (Handayanto et al., 1997). Resource quality parameters and indices related to decomposition and nutrient release in natural ecosystems were described by Swift et al. (1979), Schlesinger \& Hasey (1981) and Melillo et al. (1982). Numerous studies have since reported on nutrient contents, resource quality, decomposition, and nutrient release patterns for a variety of organic materials in tropical agroecosystems (Palm, 1995; Cadisch \& Giller, 1997; Heal et al., 1997; Mafongoya et al., 1998).

The decomposition rates and $\mathrm{N}$ release in leguminous plant residues with high $\mathrm{N}$ content are usually high (Swift et al., 1979; Ladd et al., 1981, Hunt et al., 1988; Constantinides \& Fownes, 1994a). Contents of $\mathrm{N}$, lignin and polyphenol are chemical factors that control the degradation of plant materials in the soil (Constantinides \& Fownes, 1994a). In general, increasing lignin concentration reduces the residue decomposition rate (Meentemeyer, 1978; Tian et al., 1992; Moorhead et al., 1996). High lignin 
contents could also enhance nutrient immobilization, especially of N (Melillo et al., 1982). However, Vallis \& Jones (1973) and Palm \& Sanchez (1991) found that $\mathrm{N}$ release patterns are more dependent on polyphenol content. Furthermore, the initial lignin:N ratios and the lignin + polyphenol: $\mathrm{N}$ ratios were strongly correlated with the $\mathrm{N}$ mineralization rates or $\mathrm{N}$ accumulation (Handayanto et al., 1997).

In many soils, $\mathrm{P}$ availability is heavily restricted by binding to $\mathrm{Fe}$ and $\mathrm{Al}$ oxides and by the fact that it moves through the soil profile by diffusion rather than with flowing water. Only a small fraction of the organic P pool (about $1 \%$ per year), is mineralized, supplying inorganic $\mathrm{P}$ for plant uptake (Tiessen et al., 1984). Organic $P$ transformation in the soil is difficult to study because of the reaction of inorganic $\mathrm{P}$ with various soil minerals. In most ecosystems the $\mathrm{P}$ available for biogeochemical cycling is contained in organic forms (Chapin et al., 1978; Wood et al., 1984; Yanai 1992; Gressel et al., 1996). Quality factors known to control $\mathrm{P}$ availability patterns of organic inputs are total P, C/P and N/P ratios (Singh \& Jones, 1976; Vogt et al., 1986), which are highly variable in terms of the critical levels. Net mineralization of $\mathrm{P}$ from organic matter usually begins at $\mathrm{C} / \mathrm{P}$ ratios $<$ 200 (Schlesinger, 1997).

Across large areas in the tropics of particularly Oxisols the $\mathrm{K}$, Ca and $\mathrm{Mg}$ supplies for crop needs are low (Brady, 1990). Plant residues can be an essential source of these nutrients. Information on $\mathrm{K}, \mathrm{Ca}$ and $\mathrm{Mg}$ release patterns can therefore be used to predict the potential of plant residues as sources of these nutrients. However, information about these elements is scarce.

The objective of this paper is to report results from studies on different mulch decomposition and release patterns of $\mathrm{N}, \mathrm{P}, \mathrm{K}, \mathrm{Ca}$ and $\mathrm{Mg}$ in natural fallow systems enriched with a legume tree species (Acacia angusticima, A. mangium, Clitoria racemosa, Sclerolobium paniculatum or Inga edulis), and natural fallow vegetation alone (control). These fallow systems are being evaluated in search for alternatives to the existing slash-and-mulch agriculture in the Amazon region.

\section{MATERIAL AND METHODS}

The experimental area was near Igarapé-Açú, in the Northeast of the State of Pará, in the Amazon region. The largely deforested area is dominated by subsistence crop production of small holders who use a shifting cultivation system. The strongly weathered soils of the region are typical Kandiudults (USDA Soil Taxonomy) with the following surface soil properties $(0-20 \mathrm{~cm}): 1.6 \mathrm{~g} \mathrm{~kg}^{-1}$ total $\mathrm{C}, 0.13 \mathrm{~g} \mathrm{~kg}^{-1}$ total $\mathrm{N}$, $1.3 \mathrm{mg} \mathrm{kg}^{-1}$ total $\mathrm{P}, 5.5 \mathrm{pH}$. The sand soil texture is $820 \mathrm{~g} \mathrm{~kg}^{-1}$ sand, $180 \mathrm{~g} \mathrm{~kg}^{-1}$ clay at $1.3 \mathrm{~g} \mathrm{~cm}^{-3}$ density. Total rainfall ranges from 2.000 to $3.000 \mathrm{~mm}_{\text {year }}{ }^{-1}$ with three months of sparse rain (SeptemberNovember). Annual temperature averages between $25-27^{\circ} \mathrm{C}$, and relative humidity is $80-90 \%$.

The decomposition study was conducted for one year (1997-1998), after slashing and mulching the standing aboveground biomass of a 30-month-old experimental stand to investigate the dynamics of fallow vegetation enriched with the following leguminous tree species: Acacia mangium Willd (total aboveground biomass $\left.=55.6 \mathrm{Mg} \mathrm{ha}^{-1}\right), A$. angustissima Kuntze (33.5 $\mathrm{Mg}^{-1} \mathrm{~h}^{-1}$ ), Sclerolobium paniculatum Vogel (32.2 Mg ha-1), Inga edulis Mart. (30.0 $\left.\mathrm{Mg} \mathrm{ha}^{-1}\right)$, and Clitoria racemosa G. Don (27.2 $\mathrm{Mg} \mathrm{ha}^{-1}$ ) (Brienza Jr., 1999). Secondary forest regrowth was used as control (24.0 Mg ha-1), but the regrowth being an enrichment with leguminous species this also finds in the other treatments. Samples of bulked fresh material were collected from the five leguminousspecies treatments with presumably contrasting litter quality characteristics and one mixed sample from the control (Table 1).

Residue decomposition and nutrient release were studied using fine-mesh litterbags $(11 \times 9 \mathrm{~cm}$, meshsize $<0.2 \mathrm{~cm})$. About $25 \mathrm{~g}$ of ground air-dried material ( $>0.2 \mathrm{~cm}$, equivalent to $25 \mathrm{Mg} \mathrm{ha}^{-1}$ ) per leguminous tree were placed in each bag. The quantity of biomass included in the litterbags was calculated in $\mathrm{Mg} \mathrm{ha}^{-1}$, based on the production results of Brienza Jr. (1999) and the bag surface area. In this way, treatment levels included five pure leguminous

Table 1. Initial chemical composition of litterbag material from different leguminous species and control (fallow vegetation) used in the decomposition experiment. Average(stand error)

\begin{tabular}{|c|c|c|c|c|c|c|c|c|c|c|}
\hline Specie & $\mathbf{N}$ & C & $\mathrm{C} / \mathrm{N}$ & $\mathbf{P}$ & $\mathbf{K}$ & $\mathbf{C a}$ & Mg & Lignin & Cellulose & Phenol \\
\hline & \multicolumn{2}{|c|}{$\mathrm{g} \mathrm{kg}^{-1}$} & & \multicolumn{4}{|c|}{$\longrightarrow \mathrm{g} \mathrm{kg}^{-1}$} & $\longrightarrow$ & $\%$ & 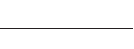 \\
\hline A. angustissima & $8.3(0.14)$ & $510.7(1.23)$ & $61.4(1.16)$ & $0.77(0.02)$ & $13.3(1.43)$ & $6.5(0.12)$ & $2.6(0.51)$ & $18.3(0.17)$ & $54.0(0.68)$ & $29.7(1.27)$ \\
\hline A. mangium & $5.0(0.30)$ & $496.5(3.39)$ & $101.1(6.04)$ & $0.31(0.00)$ & $6.7(1.44)$ & $11.1(0.34)$ & $2.9(0.61)$ & $26.5(0.31)$ & $46.9(0.26)$ & $19.1(1.28)$ \\
\hline C. racemosa & $7.8(0.08)$ & $482.6(2.50)$ & $61.6(0.39)$ & $0.68(0.09)$ & $11.6(0.89)$ & $7.9(0.06)$ & $2.6(0.43)$ & $23.8(0.91)$ & $44.6(0.17)$ & $11.6(0.84)$ \\
\hline Control & $10.1(0.90)$ & $475.2(2.78)$ & $48.4(4.24)$ & $0.41(0.03)$ & $5.3(0.60)$ & $9.6(1.01)$ & $1.6(0.36)$ & $28.5(1.20)$ & $41.4(0.53)$ & $10.8(1.11)$ \\
\hline I. edulis & $7.2(0.11)$ & $494.7(0.59)$ & $61.1(0.99)$ & $0.74(0.01)$ & $13.5(0.98)$ & $11.0(0.05)$ & $2.7(0.34)$ & $31.4(0.97)$ & $44.1(1.23)$ & $20.6(1.78)$ \\
\hline S. paniculatum & $8.6(0.09)$ & $458.2(2.72)$ & $53.4(0.78)$ & $0.39(0,02)$ & $5.9(1.08)$ & $8.8(0.38)$ & $1.7(0.15)$ & $29.5(1.50)$ & $41.8(1.29)$ & $11.3(0.67)$ \\
\hline
\end{tabular}


species and a mixture of spontaneous regrowth (control).

Nine litterbags per treatment for each time (total per treatment $=36$ ) were placed randomly on three of the $10 \times 8 \mathrm{~m}$ plots, where the same species had grown before felling the trees. Care was taken that the litterbags were covered by chopped material. In order to test the external influence of the organic material from remaining mulch, three litterbags per sampling date were placed outside the plot without mulch contact. The residue litterbags were removed, brushed free of foreign material (including roots) and dried 0 , $6,12,24,48,96$, and 362 days after the beginning of the experiment.

The dry matter content and all parameter analyses were corrected for ash content (Blair et al., 1990). The samples from each treatment were ground and analyzed for total $\mathrm{C}$ and $\mathrm{N}$ by analyzer Carlo Erba (Carlo Erba elementary analysis). For the determination of $\mathrm{P}, \mathrm{K}, \mathrm{Ca}$ and $\mathrm{Mg}$ the materials were wet-digested with a mixture of $\mathrm{HClO}_{4}-\mathrm{HNO}_{3}$. Phosphorus was measured colorimetrically by an autoanalyzer, $\mathrm{K}$ was measured by flame photometry, and $\mathrm{Ca}$ and $\mathrm{Mg}$ were measured using atomic absorption spectrophotometry (IITA, 1982). Lignin and cellulose content was measured using the acid detergent fibre method (van Soest \& Wine, 1968), and soluble polyphenolics by the revised Folin-Denis method (Constantinides \& Fownes, 1994b). The tissue:solvent ratio of $1 \mathrm{mg} \mathrm{mL}^{-1}$ was extracted with $50 \%$ methanol at approximately $80^{\circ} \mathrm{C}$ for one hour.

Ash-free dry weight of remaining plant material and decomposition rate constants were analyzed using one-way analysis of variance (one-way ANOVA) and multivariate analysis to determine differences in decomposition (i.e. correlation, multiple regression and principal components discriminate analysis methods). Single $\left(A_{t}=e^{-k t}\right)$ and double $\left[A_{t}=S e^{-k t}+(1-S) e^{-h t}\right]$ exponential equations were used to calculate the decomposition rate constants (Wieder \& Lang, 1982), where $A_{t}$ is the proportion of remaining material at time $t ; S$ is the initial proportion of labile material; $(1-S)$ is the initial resistant proportion; $k$ is the rate constant for the labile component; and $h$ is the rate constant for resistant component. All statistical analyses were performed using the SYSTAT program.

\section{RESULTS AND DISCUSSION}

\section{Chemical composition of fallow species}

The nutrient contents of the material in the litterbags (Table 1) were variable. A. angustissima contained the highest initial concentration of $\mathrm{P}$, cellulose and phenol and the lowest $\mathrm{Ca}$ and lignin concentration. A. mangium had the highest initial $\mathrm{Ca}$ and $\mathrm{Mg}$, and the lowest $\mathrm{N}$ and $\mathrm{P}$ concentration. C. racemosa had intermediate concentrations of all materials analyzed. In the control treatment the initial $\mathrm{N}$ concentration was highest and the initial concentration in $\mathrm{K}, \mathrm{Mg}$, cellulose and phenol lowest. The I. edulis treatment had the highest initial $\mathrm{K}$ and Ca concentration, and $S$. paniculatum the highest initial lignin concentration.

Because all treatments had initial $\mathrm{C}: \mathrm{N}$ ratios of more than 40, an initial nutrient immobilization was to be expected (Stevenson and Cole 1999). Nutrients such as $\mathrm{N}$, which are often limiting for microbial growth, are immobilized where $\mathrm{C}$ supply is plentiful and nutrient concentrations are low and mineralized as $\mathrm{C}$ content decreases and nutrient concentration increases (Stevenson and Cole 1999).

\section{Patterns of organic matter decomposition}

A rapid decrease in ash-free dry weight was observed in $C$. racemosa and $A$. mangium prunings during 96 days of field incubation (Figure 1). The $A$. mangium treatment lost weight faster in the first week of the experiment, but was slower than $C$. racemosa thereafter. No significant differences $(p>0.05)$ in decomposition rates were observed between $A$. angustissima, S. paniculatum, I. edulis, and the control (fallow vegetation).

After 362 days the litterbag weight was reduced due to decomposition by $64.9 \%$ (A. angustissima), $71.7 \%$ (I. edulis), $73.8 \%$ (S. paniculatum), $78.9 \%$ (control), $86.3 \%$ (A. mangium), and $97.0 \%$ ( $C$. racemosa) (Figure 1). Weight losses of $C$. racemosa and $A$. mangium (Figure 1) differed significantly from each other $(\mathrm{p}>0.05, \mathrm{n}=316)$ and also when each was compared to the other three species ( $A$. angustissima, S. paniculatum, I. edulis, and control). The differences in total weight losses in $S$. paniculatum, I. edulis and the control treatment were not significant. The biomass loss from $A$. mangium was significantly higher, approximately $48.0 \mathrm{Mg} \mathrm{ha}^{-1}$,

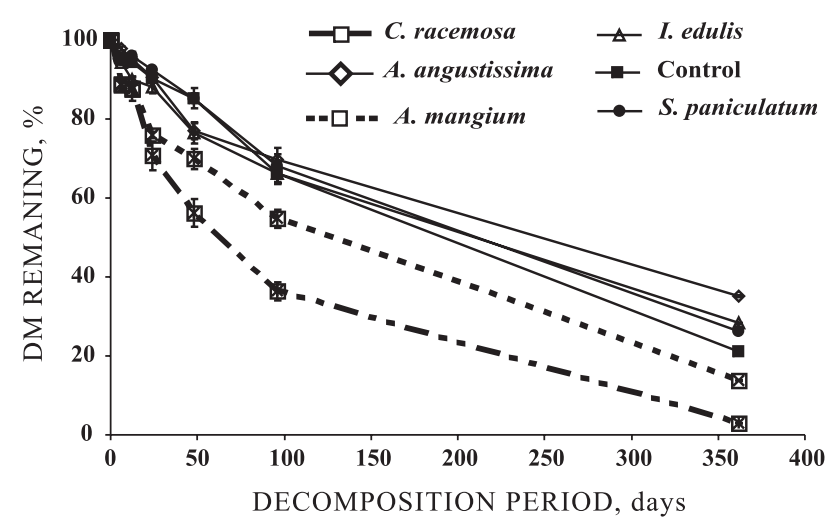

Figure 1. Remaining dry mater (DM) in litter bags of residues of five leguminous species and fallow vegetation (control) during decomposition period. Bars represent stand error. 
since after 2.5 fallow years the aboveground biomass of this species was 2.3 times greater than the natural fallow vegetation (Brienza Jr., 1999). On the other hand, at the end of the experiment the remaining mulch biomass of $C$. racemosa was the lowest with $0.9 \mathrm{Mg} \mathrm{ha}^{-1}$ (3.3\% of initial mulch biomass).

Exponential curves fitted well to the decomposition data of each species (Table 2). The double exponential curve fit best with data for $C$. racemosa and $A$. mangium (Pearson correlation coefficient $=0.951$ for both species). The data for all species studied as well as the control fitted best to a double exponential curve during the first week of the litterbag decomposition experiment (Table 2). Although differences between the two models were not significant, the double exponential curve was better correlated with fast OM decomposition, and the slow mass loss was better correlated with the single exponential curve (Table 2).

The exponential weight loss pattern agrees with the assumption that residues contain labile and recalcitrant fractions with different degrees of resistance to microbial degradation. Reinerstsen et al. (1984) associated the more rapid decay immediately after residue burial with the decomposition of watersoluble organic contents. Hunt et al. (1988) explained differences in decomposition patterns and rates among substrates as related to the amount of labile or rapidly decomposing fractions (sugar, starches, proteins) and the recalcitrant or slowly decomposing fraction (cellulose, lignin, fats, tannins, and waxes).

\section{Nitrogen and carbon release}

The decomposition patterns of ash-free $\mathrm{N}$ release was different in different leguminous plant residues (Figure 2). The increase of absolute $\mathrm{N}$ mass in the litterbags of all leguminous species studied as well as the control differed throughout the study period. An

Table 2. Correlation coefficients for single $\left(A_{t}=e^{-k t}\right)$ and double $\left(A_{t}=S e^{-k t}+(1-S) e^{-h t}\right)$ exponential equation that were used to calculate the decomposition rate constants, where $A_{t}$ is the proportion of material remaining at time $t ; S$ is the initial proportion of labile material; $(1-S)$ is the initial proportion of resistant material; $k$ is the rate constant for the labile component; and $h$ is the rate constant for the resistant component

\begin{tabular}{lcc}
\hline \multicolumn{1}{c}{ Specie } & $\mathbf{A}_{\mathrm{t}}=\mathbf{e}^{-\mathrm{kt}}$ & $\mathbf{A}_{\mathrm{t}}=\mathbf{S} \mathbf{e}^{-\mathrm{k} \mathrm{t}}+(\mathbf{1 - S}) \mathbf{e}^{-\mathrm{h} \mathrm{t}}$ \\
\hline A. angustissima & 0.9337 & 0.9240 \\
A. mangium & 0.9347 & 0.9506 \\
C. racemosa & 0.9485 & 0.9510 \\
Control & 0.9240 & 0.9549 \\
I. edulis & 0.9190 & 0.9117 \\
S. paniculatum & 0.8788 & 0.8366 \\
\hline
\end{tabular}

initial $\mathrm{N}$ decline (0-6 days) was observed for $A$. angustissima only. Nitrogen accumulations depended significantly on the species and decomposition period. The $\mathrm{N}$ content remained stable during the first 96 days of field decomposition in A. mangium, I. edulis and the control and thereafter decreased slightly in I. edulis only (Figure 2). The $\mathrm{N}$ accumulation of $A$. mangium was highly significant until 96 days of litter bag incubation and dropped abruptly afterwards.

Immobilization of $\mathrm{N}$ in litterbag material was also observed in litterbags without contact with the remaining mulch after 96 days of field decomposition (data not shown). Increases in $\mathrm{N}$ mass in decomposing litter of diverse wood species have been reported by Melillo et al. (1982), Hunt et al. (1988), O'Connell (1988), Blair et al. (1990), Constantinides \& Fownes (1994a), and Vitousek et al. (1994). The reasons explaining the absolute increases include additions of $\mathrm{N}$ through one or more of the subsequent mechanisms: fixation, absorption of atmospheric ammonia, throughfall, dust, insects, grass, green litter, fungal translocation and/or immobilization, bacterial development. Nutrients such as N, which are often limiting to microbial growth, are immobilized when the $\mathrm{C}$ supply is plentiful and nutrient concentrations are low and mineralized when $\mathrm{C}$ content decreases and nutrient concentration increases (O'Connell, 1988).

The coefficients of correlation between $\mathrm{N}$ accumulation or loss in litter bag material and some chemical properties of OM are shown in table 3. The leguminous species and the control have different patterns of $\mathrm{N}$ accumulation or loss, depending on the lignin:P ratio $(\mathrm{k}=0.850)$. Nitrogen accumulation or decrease in the litterbag was positively correlated with lignin content in most of the treatments. Only for $A$. mangium and $I$. edulis, with a higher initial phenol concentration, $\mathrm{N}$ accumulation was negatively correlated with phenol.

All treatments were significantly negatively correlated with phenol content and $\mathrm{N}$ accumulation or decrease in litterbag material. The ratios C:N and (lignin + phenol): $\mathrm{N}$ were highly significantly correlated with $\mathrm{N}$ accumulation. The correlation of A. angustissima, A. mangium, and S. paniculatum was significant positive between $\mathrm{N}$ accumulation and $\mathrm{P}$ whereas the correlation of I. edulis was significant negative. The $S$. paniculatum treatment had a significant positive correlation between $\mathrm{N}$ accumulation and $\mathrm{P}$ and $I$. edulis a significant negative correlation for the same parameters. The control and C. racemosa were not significantly correlated with $\mathrm{P}$.

Berendse et al. (1987) and Muller et al. (1988) reported that $\mathrm{N}$ release was reduced at high lignin concentrations. Lignin is known to be a recalcitrant substance and highly resistant to microbial decomposition (Melillo et al., 1982). This study, however, showed that the species with a higher initial 

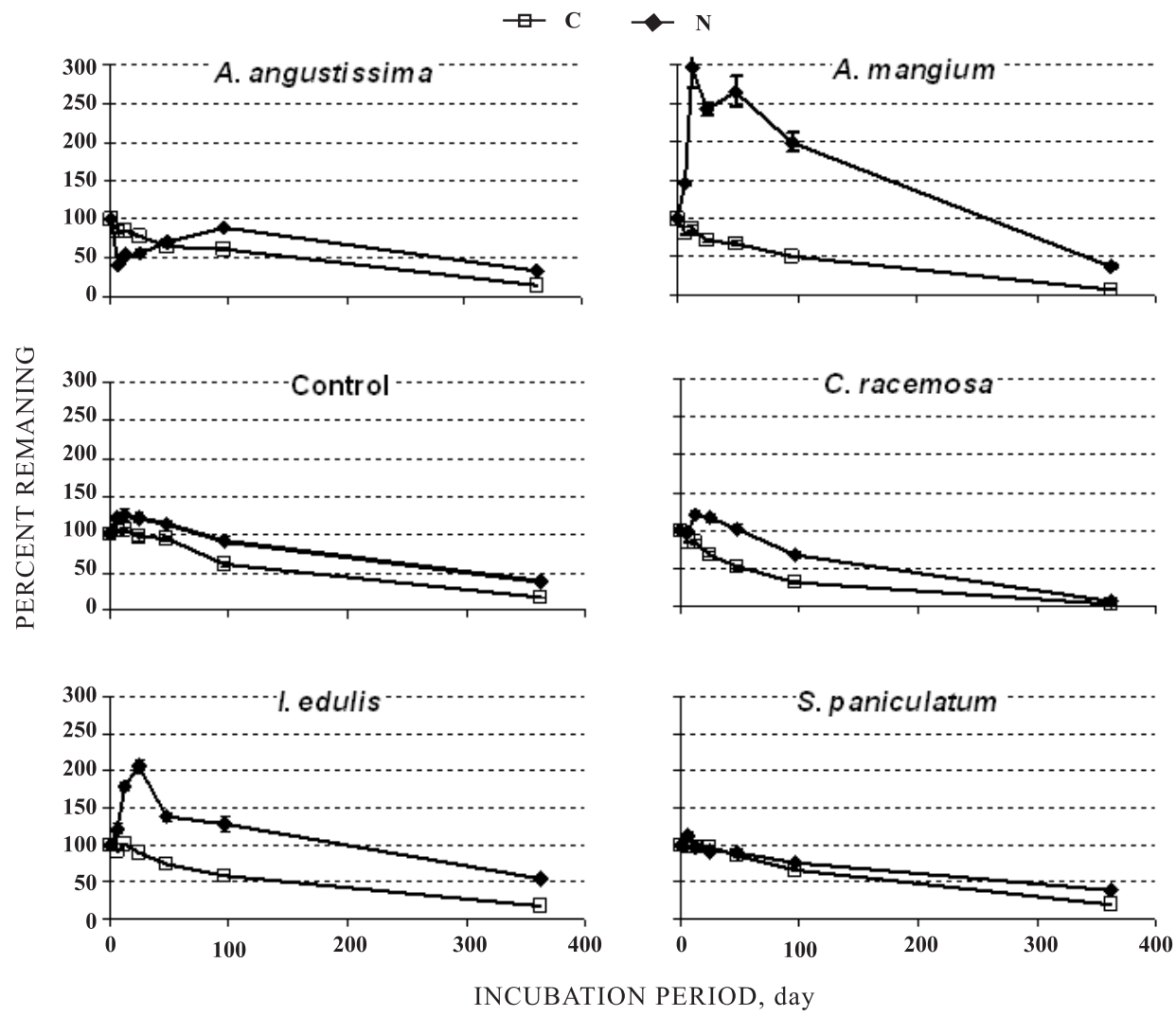

Figure 2. Remaining $\mathrm{N}$ and $\mathrm{C}$ in litter bags material during decomposition experiment for five leguminous species and a fallow vegetation (control). Bars represent stand error.

Table 3. Coefficients of determination $\left(r^{2}\right)$ for linear regressions between initial substrate quality variables from some legumes species and natural fallow vegetation (as control) and $\mathrm{N}$ mineralization rate constants after one year of field decomposition

\begin{tabular}{lcc}
\hline $\begin{array}{c}\text { Mulch initial quality } \\
\text { variable }\end{array}$ & $\begin{array}{c}\text { N Mineralization } \\
\text { ratio constant, } k\end{array}$ & $\begin{array}{c}\text { Percentage of N observed } \\
\text { after 1 year }\end{array}$ \\
\hline day & & $0.806^{* *}$ \\
Phenol & & $0.839^{* *}$ \\
Lignin + phenol & $0.704^{*}$ & $0.752^{*}$ \\
C-to-N ratio & $0.222^{\mathrm{ns}}$ & $0.731^{*}$ \\
C & $0.541^{\mathrm{ns}}$ & $0.764^{*}$ \\
Phenol + lignin-to-N ratio & $0.701^{*}$ & $0.792^{*}$ \\
Phenol-P ratio & $0.632^{\mathrm{ns}}$ & $0.757^{*}$ \\
Lignin-to-P ratio & $0.596^{\mathrm{ns}}$ & $0.730^{*}$ \\
Phenol + lignin-to-P ratio & $0.850^{* *}$ & $0.793^{*}$ \\
Phenol-to-cellulose ratio & $0.704^{*}$ & $0.871^{* *}$ \\
\hline
\end{tabular}

ns: not significant; ${ }^{*}$; significant at $\mathrm{p}<0.05$; and ${ }^{* *}$ : significant at $\mathrm{p}<0.01$.

lignin concentration (S. paniculatum, Fallow and $A$. angustissima) (Table 1) were positively correlated with $\mathrm{N}$ release in mulch. It has also been found that lignin with two phenolic hydroxyls could fix $\mathrm{N}$, part of which was resistant to $72 \%$ sulphuric acid or strong alkaline solution (Bennett, 1949). 


\section{Phosphorus remaining in mulch}

The remaining $\mathrm{P}$ decreased during the first week of litterbag exposure in all treatments (Figure 3). But after three weeks, $\mathrm{P}$ immobilization increased significantly in all treatments (Figure 3). Phosphorus immobilization may be due to the low initial $\mathrm{P}$ concentrations in plant residues (Buldeman, 1998). Some authors have shown that the release of $\mathrm{P}$ is limited in many tropical soils and is often the most limiting nutrient (Palm \& Sanchez, 1990; Tian et al., 1992; Thomas \& Asakawa, 1993). Usually during fallow, immobilization phases that could aggravate soil solution $\mathrm{P}$ deficiencies relative to crop demand (Palm, 1995). This study confirms that a potential increase of $\mathrm{P}$ availability due to release from decomposing plant residues could be an important criterion for selecting species for enriched fallow systems.

As also found by Kato (1998) at the same experimental site, our study showed that the low $\mathrm{P}$ content in the control and legume material resulted in a high C:P ratio (Figure 4). The C:P ratios in the $A$. angustissima, S. paniculatum and $I$. edulis treatments increased in the first seven weeks of the experiment. For the other treatment the C:P ratio was constant during the experiment. Sanchez (1976) showed that C:P and C:N ratios are indicators of $\mathrm{P}$ deficiency and suggest that $\mathrm{P}$ is mineralized at about the same rate as organic $\mathrm{C}$. This hypothesis was confirmed in the case of $A$. mangium, $C$. racemosa and the control treatment, but not for S. paniculatum and I. edulis.
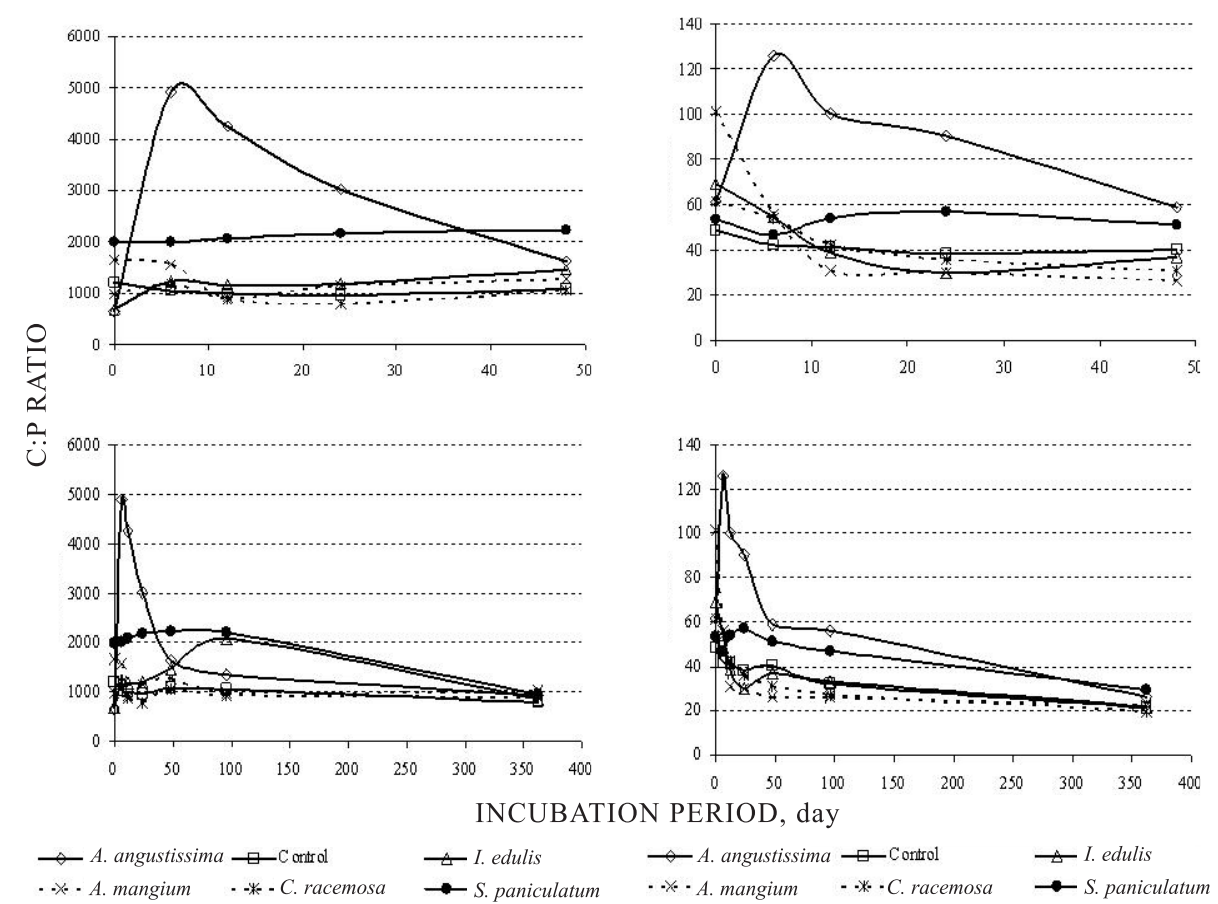

Figure 4. Carbon-to-P ratio and N-to-P ration for different legume treatment and control (as natural fallow vegetation), for 48 and 362 days of incubation period. 
In all treatments the $\mathrm{N}: \mathrm{P}$ ratio increased during the incubation period (Figure 4). The decrease in the $\mathrm{N}: \mathrm{P}$ ratio in $I$. edulis and $S$. paniculatum was higher after 96 incubation days. The increasing N:P ratios during decomposition imply that organic $\mathrm{P}$ was mineralized at a slower rate than organic N. Fungal translocation and/or immobilization may be the processes that increased $\mathrm{P}$ in the remaining mulch.

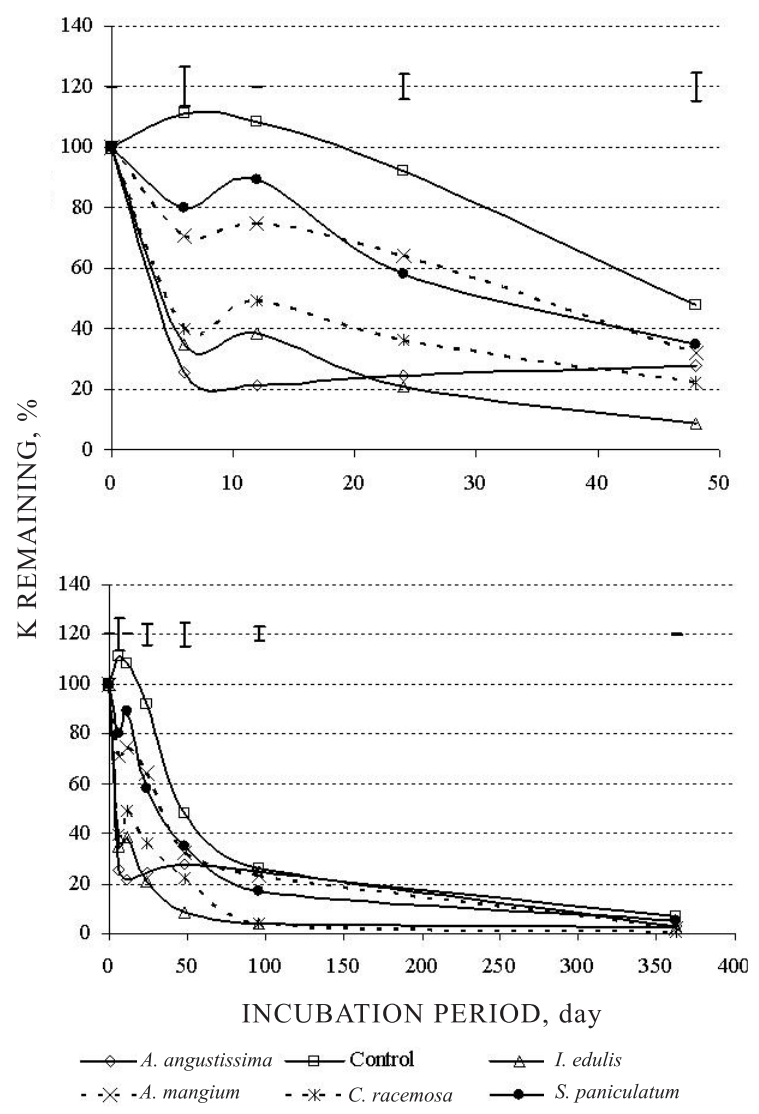

Figure 5. Percentages of $\mathrm{K}$ remaining in mulch from different enriched legumes trees and natural fellow as control, for 48 and 362 days of incubation period. Bars represent LSD with $p<0.05$.

\section{Remaining potassium in mulch}

The patterns for $\mathrm{K}$ mineralization were different in the mulch material from different legume species and the control (Figure 5). The $\mathrm{K}$ release in all treatments was fast, mainly in the case of $I$. edulis and $C$. racemosa, which lost approximately $80 \%$ of the initial $\mathrm{K}$ in the first three weeks of field decomposition. At the end of the incubation period the release of remaining $\mathrm{K}$ in mulch biomass was very low for all legume species and the control. However, the remaining $\mathrm{K}$ in the control treatment was highest in comparison with the other treatments.

Potassium in plants occurs mainly in a soluble ionic form (Tukey, 1970). The cell structure of the organs included in the mulch is largely lost. Potassium can therefore be easily leached from litter and the losses are certainly accelerated by high rainfall. Potassium release from mulch is rather fast since 93.1 to $99.6 \%$ of initial K concentration returns to the soil during the first year of decomposition. At the end of the experiment there were no significant differences among the treatments

In general, $\mathrm{K}$ losses were highly positively correlated with phenol and $\mathrm{C}$ concentration during the incubation period across all treatments (Table 4). This suggests that $\mathrm{K}$ mineralization dependeds on phenol and $\mathrm{C}$ concentration during the incubation period. However, the coefficient of correlation with $\mathrm{K}$ concentration of $\mathrm{P}$ was higher for control and I. edulis treatment. The initial K concentration in these treatments was lowest and highest (Table 1), respectively.

\section{Calcium remaining in mulch}

Release of Ca from all treatments increased during incubation (Figure 6). Only in the A. angustissima and $I$. edulis treatments there was no initial $\mathrm{Ca}$ immobilization, and a significantly higher increase was observed in the control and $S$. paniculatum treatments. At the end of incubation, Ca release in $A$. angustissima was significantly lower than in the other treatments.

Table 4. Correlation coefficients from regressions of potassium concentration $\left(\mathrm{g} \mathrm{kg}^{-1}\right)$ and remaining dry matter (g) and some chemical properties $\left(\mathrm{g} \mathrm{kg}^{-1} \mathrm{DM}\right)$ during the incubation period. $n=54$

\begin{tabular}{lcccccccc}
\hline Treatment & $\mathbf{N}$ & $\mathbf{C}$ & $\mathbf{P}$ & Lignin & Cellulose & Phenol & Mg & Ca \\
\hline A. mangium & 0.345 & 0.826 & 0.518 & 0.543 & 0.804 & 0.821 & 0.464 & 0.573 \\
C. racemosa & 0.684 & 0.845 & 0.747 & 0.664 & 0.776 & 0.722 & 0.632 & 0.539 \\
Control & 0.638 & 0.762 & 0.922 & 0.811 & 0.723 & 0.872 & 0.665 & 0.563 \\
I. edulis & 0.242 & 0.656 & 0.814 & 0.576 & 0.627 & 0.825 & 0.464 & 0.229 \\
S. paniculatum & 0.584 & 0.678 & 0.572 & 0.574 & 0.711 & 0.686 & 0.593 & 0.557 \\
\hline
\end{tabular}




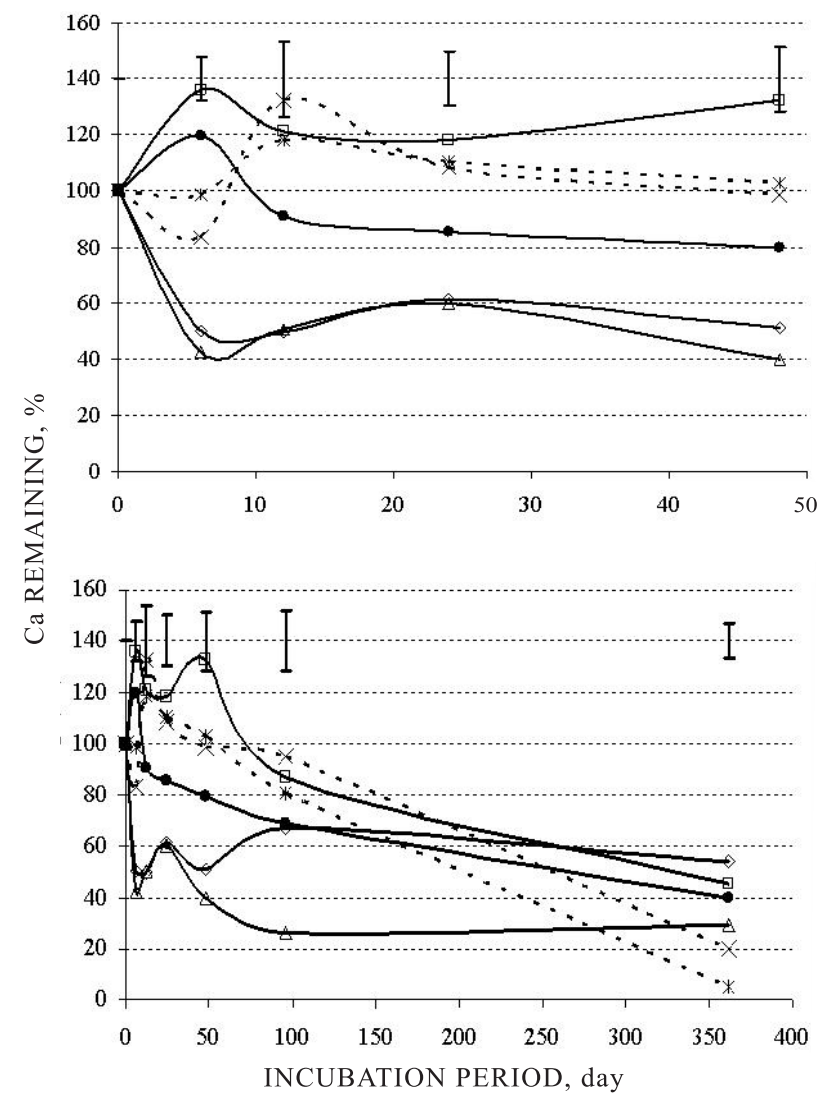

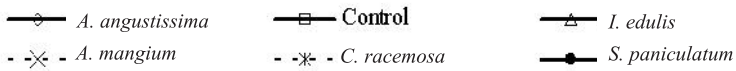

Figure 6. Percentages of Ca remaining in mulch from different enriched legumes trees and natural fellow as control, for 48 and 362 days of incubation period. Bars represent LSD with $\mathrm{p}<0.05$.

The same slow Ca release in approximately the first 14 weeks of incubation was reported by Swift et al. (1981), which is however contradictory to results of Tian et al. (1992), except in the case of Acio, where no Ca was released. The net accumulation period for Ca is probably due to luxury uptake of this element into fungal hyphae as documented by Cromack et al. (1978) and Swift et al. (1981). This would be consistent with microbial immobilization of $\mathrm{N}$ and $\mathrm{P}$ as shown above. Normally, when all treatments were considered, the positive correlation of $\mathrm{Ca}$ losses with $\mathrm{N}$ and $\mathrm{Mg}$ concentration was higher during the incubation period (Table 5).

\section{Magnesium remaining in mulch}

Similarly as shown above, the patterns of $\mathrm{Mg}$ release from mulch material were different in treatments and control (Figure 7). Only in the control and $S$. paniculatum $\mathrm{Mg}$ accumulation was significantly higher during the first week of field decomposition. In the $A$. angustissima, $C$. racemosa, $I$. edulis and $A$. mangium treatments $\mathrm{Mg}$ release was highest during the 14 weeks of incubation period. But at the end of the experiment, the $\mathrm{Mg}$ concentration was only lower than $20 \%$ of the initial concentration in $C$. racemosa $(2.5 \%)$ and A. mangium (8.1\%) (Figure 7). Generally, the Mg losses were positively correlated with $\mathrm{N}$ and $\mathrm{Ca}$ concentration during the incubation period (Table 6).

As shown earlier by Swift et al. (1981), the patterns of nutrient loss from litterbags are contrasting for different organic matter quality. This indicates a complex interplay of different processes during mulch decomposition. The role of microorganisms in mulch decomposition and nutrient immobilization is very important. Also, the amount of nutrients released depends on the intrinsic material quality and the amount of organic materials in the mulch.

Nitrogen, $\mathrm{P}, \mathrm{Ca}$ and $\mathrm{Mg}$ release from plant residues followed different decomposition patterns. Nitrogen release rates varied with species and amount of plant residues. The $\mathrm{N}$ mineralization patterns of the plant material closely reflected the differences in their chemical composition. In all species studied, including the control (natural fallow vegetation) $\mathrm{N}$ was immobilized at some time during decomposition. Furthermore, the increase in $\mathrm{N}$ concentration does not seem to have been influenced by the remaining material, because litterbags without remaining mulch

Table 5. Correlation coefficients from regressions of calcium concentration $\left(\mathrm{g} \mathrm{kg}^{-1}\right)$ and remaining dry matter (g) and some chemical properties $\left(\mathrm{g} \mathrm{kg}^{-1} \mathrm{DM}\right)$ during the incubation period. $n=54$

\begin{tabular}{lcccccccc}
\hline Treatment & N & C & P & Lignin & Cellulose & Phenol & Mg & K \\
\hline Control & 0.823 & 0.847 & 0.772 & 0.855 & 0.726 & 0.628 & 0.832 & 0.563 \\
I. edulis & 0.464 & 0.351 & 0.357 & 0.539 & 0.129 & 0.285 & 0.472 & 0.229 \\
A. mangium & 0.829 & 0.801 & 0.870 & 0.888 & 0.448 & 0.526 & 0.875 & 0.573 \\
C. racemosa & 0.934 & 0.691 & 0.721 & 0.825 & 0.477 & 0.407 & 0.700 & 0.539 \\
S. paniculatum & 0.901 & 0.688 & 0.647 & 0.681 & 0.607 & 0.812 & 0.960 & 0.557 \\
\hline
\end{tabular}




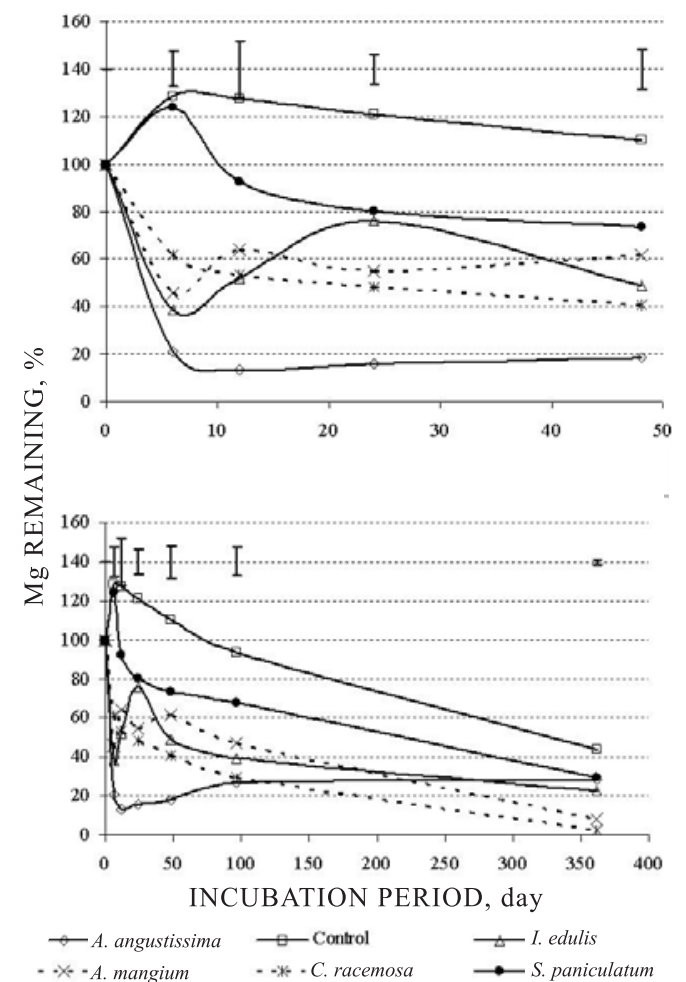

Figure 7. Percentages of Mg remaining in mulch from different enriched legumes trees and natural fellow as control, for 48 and 362 days of incubation period. Bars represent LSD with $\mathbf{p}<0.05$.

also showed an increase in $\mathrm{N}$ concentration during the decomposition period. Carbon: $\mathrm{N}$ ratios and polyphenol:P ratios appeared better correlated with $\mathrm{N}$ immobilization for all species and the control vegetation. The data suggest that $\mathrm{Mg}$, lignin and $\mathrm{Ca}$ were strongly correlated with $\mathrm{N}$ immobilization (Figure 8). The importance of $\mathrm{Ca}$ and $\mathrm{Mg}$ for $\mathrm{P}$ maintenance in mulch material seems to be due to nutrient deficiencies in acid soils and the competition for these elements between microorganism absorption and soil adsorption.
Some suggestion can be formulated to explain the increases in $\mathrm{N}$ concentration during decomposition in the litterbags. High polyphenol and lignin concentrations (Figure 9) may be a major factor in $\mathrm{N}$ immobilization during decomposition. Leaching of a major fraction of soluble polyphenol in mulch might be responsible for the formation of stable polymers with many $\mathrm{N}$ forms. This results in $\mathrm{N}$ immobilization often restricts microbial growth; this nutrient is immobilized when the C supply is plentiful and nutrient concentrations are low. Therefore, $\mathrm{N}$ is mineralized as the $\mathrm{C}$ content decreases and nutrient concentrations increase.

All treatments showed a fast initial decrease in $\mathrm{P}$ concentration during the first week of the incubation period but ended with an increase in $\mathrm{P}$ at the end of experiment. This indicates some initial $\mathrm{P}$ immobilization in all plant residues that may be due to the low initial $\mathrm{P}$ concentration in plant residues and the suggested higher microorganism activity in mulch (principally fungal growth, which can translocate this element from soil to mulch). By the end of the experiment, on average (pooled over all treatments), $3.3 \% \pm 0.9$ (mean \pm STE), $32.2 \% \pm 6.7$, and $22.4 \% \pm 5.6$ initial $\mathrm{K}, \mathrm{Ca}$ and $\mathrm{Mg}$, respectively, remained in the mulch after 362 days of field incubation. Palm \& Sanchez (1990), Thomas \& Asakawa (1993) and Lupwayi \& Haque (1999) reported greater loss of $\mathrm{K}$ than of any other nutrient from decomposing leguminous tree litter and immobilization of $\mathrm{Ca}$ and $\mathrm{Mg}$. Furthermore, Tian et al. (1992) observed a more rapid release of $\mathrm{K}$ than of the other nutrients, although $\mathrm{Ca}$ and $\mathrm{Mg}$ release fast as well.

In accordance with Palm \& Sanchez (1991), the use of legume trees with low polyphenol content as mulch can release $\mathrm{N}$ and provides this nutrient for crop growth. Legumes with high levels of polyphenols that may react with organic $\mathrm{N}$ compounds are not favorable for adequate $\mathrm{N}$ levels for plant growth in the short term. However, they may contribute to the build-up of soil organic $\mathrm{N}$ and result in a low but continuous $\mathrm{N}$ supply in the long term. From our results it appears that the mixing of two contrasting

Table 6. Correlation coefficients from regressions of magnesium concentration ( $\left.\mathrm{g} \mathrm{kg}^{-1}\right)$ and some chemical properties $\left(\mathrm{g} \mathrm{kg}^{-1} \mathrm{DM}\right)$ during the incubation period. $n=54$

\begin{tabular}{|c|c|c|c|c|c|c|c|c|}
\hline Treatment & $\mathbf{N}$ & $\mathrm{C}$ & $\mathbf{P}$ & Lignin & Cellulose & Phenol & $\mathrm{Ca}^{2+}$ & $\mathbf{K}^{+1}$ \\
\hline Control & 0.915 & 0.834 & 0.691 & 0.537 & 0.770 & 0.678 & 0.832 & 0.665 \\
\hline I. edulis & 0.786 & 0.469 & 0.468 & 0.505 & 0.225 & 0.217 & 0.472 & 0.464 \\
\hline A. mangium & 0.916 & 0.769 & 0.810 & 0.942 & 0.378 & 0.470 & 0.875 & 0.464 \\
\hline C. racemosa & 0.915 & 0.826 & 0.856 & 0.862 & 0.769 & 0.661 & 0.700 & 0.632 \\
\hline S. paniculatum & 0.883 & 0.697 & 0.632 & 0.668 & 0.641 & 0.788 & 0.960 & 0.593 \\
\hline
\end{tabular}



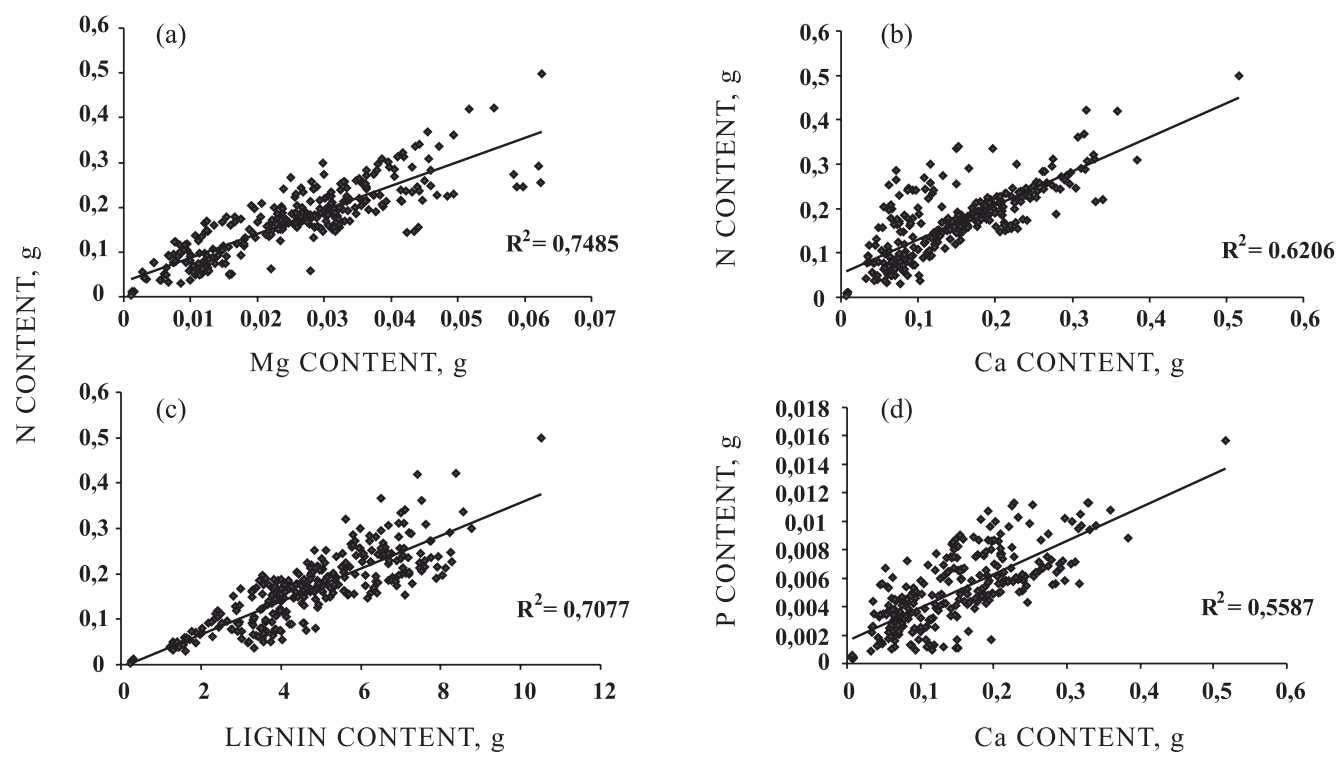

Figure 8. The better correlation of some nutrients and mulch characteristics: $\mathrm{N}$ content with Mg content (a), Ca content (b) and lignin content (c), and correlation of phosphorus content and Ca content. The correlation was made during the incubation time of litterbag with different material content.
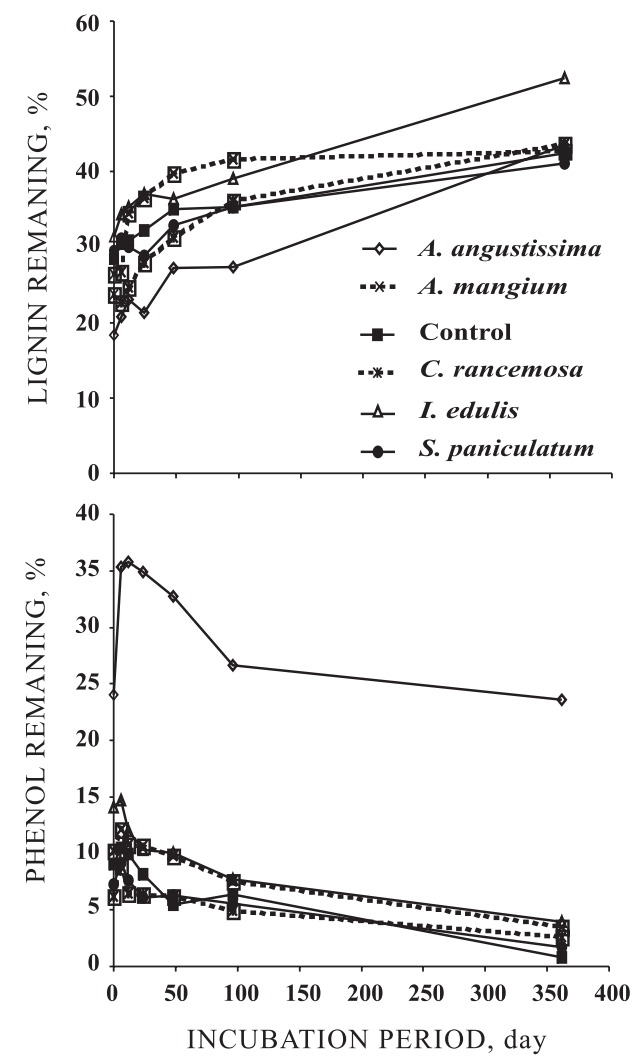

Figure 9. Percentages of lignin and phenol remaining in mulch from different enriched legumes trees and natural fellow as control.

trees in terms of litter quality would provide the best fallow management when the alternative mulch system is used.
The need of increasing agricultural yields cannot be met by a major expansion of cultivated areas alone, so the intensification of land use and improvement of currently cultivated soil is indispensable. An enriched fallow management with slash and mulch system can be an option to restore soil organic matter and maintain nutrients in the humid tropical ecosystem. Studies of systems enriched with contrasting leguminous species in terms of nutrient mineralization and the organic $\mathrm{C}$ :nutrient ratio in decomposing biomass will provide insights into which species to use for fallow enrichment. The sustainability of the slash-and-mulch system should not only be judged by the crop yield stability but also by the efficiency of an agroecosystem to maintain and recycle mineral nutrients and to prevent $\mathrm{CO}_{2}$ and nutrient release and losses from burned biomass.

\section{CONCLUSIONS}

1. These data confirm that soluble $\mathrm{C}$, which includes metabolic and storage $\mathrm{C}$, is of high quality and is primarily responsible for promoting microbial growth and activity. Large amounts of soluble $\mathrm{C}$ but little soluble $\mathrm{N}$ and $\mathrm{P}$ in decomposing plant residues induce net immobilization.

2. The patterns of nutrient mineralization in mulch observed in this study are complex and involve a variety of factors, which differed largely from decomposition of soil-incorporated organic matter. This study suggests that cellulose, as a $\mathrm{C}$ source, and polyphenol content might control the short-term $\mathrm{N}$ 
release and availability from mulch, principally $\mathrm{N}$ and P.

3. The slash-and-mulch systems with thick mulch mats need to be improved for the synchronization of nutrient release from organic material and nutrient uptake by crop systems. The use of contrasting plant material in terms of litter quality, $\mathrm{C}$ reduction in the vegetation with the selective removal of wood, and soil incorporation of fallow residues need to be further tested.

3. On the other hand, agricultural yields in the Amazon region cannot be increased by further deforestation and the possibility of an increased fertilizer use is limited. Consequently, the land use will have to be intensified by improving the currently cultivated soil. Fallow-mulch systems are promising and call for more research. The agricultural policy in the Amazon region could promote organic agriculture to start up production and use in the commercialization of organic agricultural products of the region.

\section{ACKNOWLEDGMENTS}

This study was supported by the Bundesministerium für Bildung und Forschung (German Federal Ministry of Education and Research). The paper is a part of a thesis presented by José Henrique Cattanio in partial fulfillment of the requirements for the Doctor's degree at the University of Göttingen and was supported by the National Council of Scientific and Technological Development (CNPq), Brazil.

\section{LITERATURE CITED}

ADDISCOTT, T.M.; WHITMORE, A.P. \& POWLSON, D.S Farming fertilizers and the nitrate problem. Wallingford, CAB International, 1991. 176p.

BENNETT, E. Fixation of ammonia by lignin. Soil Sci., 68:399340, 1949.

BERENDSE, F.; BERG, B. \& BOSATTA, E. The effect of lignin and nitrogen on the decomposition of litter in nutrient - poor ecosystem: A theoretical approach. Can. J. Bot., 65:1116-1120, 1987.

BLAIR, J.M.; PARMELEE, R.W. \& BEARE, M. Decay rates, nitrogen fluxes, and decomposer communities of singleand mixed-species foliar litter. Ecology, 71:1976-1985, 1990.

BRADY, N.C. The nature and properties of soils. New York, Mamillan Publishing Company, 1990.

BRIENZA Jr., S. Biomass dynamics of fallow vegetation enriched with leguminous trees in the Eastern Amazon of Brazil. Göttingen, Agricultural Sciences of the Faculty of Agricultural Sciences George-August-University Goettingen, 1999. 129p. (Tese de Doutorado)
BULDEMAN, A. The decomposition of leaf mulches of Leucena leucocephala, Gliricidia sepuim and Flemingia macrophylla under humid tropic condition. Agrof. Syst., 7:33-45, 1988

CADISCH, G. \& GILLER, K.E. Driven by nature: Plant litter quality and decomposition. Wallingford, CAB International, 1997. 409p.

CHAPIN, F.S.; BARSDATE, R.J. \& BARÈL, D. Phosphorus cycling in Alaskan coastal tundra: A hypothesis for the regulation of nutrient cycling. Oikos, 31:189-199, 1978.

CONSTANTINIDES, M. \& FOWNES, J.H. Nitrogen mineralization from leaves and litter of tropical plants: Relationship to nitrogen, lignin, and soluble polyphenol concentrations. Soil Biol. Biochem., 26:49-55, 1994a.

CONSTANTINIDES, M. \& FOWNES, J.H. Tissue-to-solvent ratio and other factors affecting determination of soluble polyphenols in tropical leaves. Comm. Soil Sci. Plant Anal., 25:3221-3227, 1994b.

CROMACK, K.; SOLLINS, P.; TODD, R.L.; FOGEL, R.; TODD, A.W.; FENDER, W.M. \& CROSSLEY, D.A. The role of oxalic acid and bicarbonate in calcium cycling by fungi and bacteria: Some possible implications for soil animals. In: LOHM, U. \& PERSSON, T., eds. Soil organisms as components of ecosystems. Stockholm, Swedish Natural Sciences Research Council, 1978. p.246-252. (Ecol. Bull., 25)

DENICH, M.; VIELHAUER, K.; KATO, M.S.A.; BLOCK, A.; KATO, O.R.; SÁ, T.D.A.; LÜCKE, W. \& VLEK, P.L.G. Mechanized land preparation in forest-based fallow systems: The experience from Eastern Amazonia. Agrofor. Syst., 61:91-106, 2004.

GRESSEL, N.; McCOLL, J.G.; PRESTON, C.M.; NEWMAN, R.H. \& POWERS, R.F. Linkages between phosphorus transformations and carbon decomposition in a forest soil. Biogeochemistry, 33:97-123, 1996.

HANDAYANTO, E.; CADISCH, G. \& GILLER, K.E. Regulating $\mathrm{N}$ mineralization from plant residues by manipulation of quality. In: CADISCH, G. \& GILLER, K.E., eds. Drive by nature: Plant litter quality and decomposition. Wallingford, CAB International, 1997. p.175-185.

HEAL, O.W.; ANDERSON, J.M. \& SWIFT, M.J. Plant litter quality and decomposition: An historical overview. In: CADISCH, G. \& GILLER, K.E., orgs. Driven by nature: Plant litter quality and decomposition. Wallingford, $\mathrm{CAB}$ International, 1997. p.3-30.

HUNT, H.W.; INGHAM, E.R.; COLEMAN, D.C. \& REID, C.P.P. Nitrogen limitation of production and decomposition in prairie, mountain meadow, and pine forest. Ecology, 69:1009-1016, 1988.

IITA. Automated and semi-automated methods for soil and plant analysis. Manual Series no. 7. IITA, Ibadan, 1982. $33 p$.

KATO, M.S.A. Fire-free land preparation as an alternative to slash-and-burn agriculture in the Bragantina Region, Eastern Amazon: Crop performance and phosphorus dynamics. Goettingen, Facultay of Agricultural Sciences, George-August-University, 1998. 132p. (Tese de Doutorado) 
KAYE, J.P. \& HART, S.C. Competition for nitrogen between plants and soil microorganisms. Tree, 12:139-143, 1997.

LADD, J.N.; OADES, J.M. \& AMATO, M. Distribution and recovery of nitrogen from legume residues decomposing in soils sown to wheat in field. Soil Biol. Biochem., 13:251256, 1981.

LUPWAYI, N.Z. \& HAQUE, I. Leucaena hedgerow intercropping and cattle manure application in the Ethiopian highlands I. Decomposition and nutrient release. Biol. Fert. Soils, 28:182-195, 1999.

MAFONGOYA, P.L.; NAIR, P.K.R. \& DZOWELA, B.H. Mineralization of nitrogen from decomposing leaves of multipurpose trees as affected by their chemical composition. Biol. Fert. Soils, 27:143-148, 1998.

MEENTEMEYER, V. Macroclimate and lignin control of litter decomposition. Ecology, 59:405-472, 1978.

MELILLO, J.M.; ABER, J.D. \& MURATORE, J.F. Nitrogen and lignin control of hardwood leaf litter decomposition dynamics. Ecology, 63:621-626, 1982.

MOORHEAD, D.L.; SINSABAUGH, A.E.; LINKINS, A.E. \& REYNOLDS, J.F. Decomposition processes: Modelling approaches and applications. Sci. Total Environ., 183:137$149,1996$.

MULLER, M.M.; SUNDMAN, V.; SOININVAARA, O. \& MERILAINEN, A. Effect of chemical composition on the release of nitrogen from agricultural plant materials decomposing in soil under field conditions. Biol. Fert. Soils., 6:78-83, 1988.

MYERS, R.J.K.; PALM, C.A.; CUEVAS, E.; GUNATILLEKE, I.U.N. \& BROSSARD, M. The synchronization of nutrient mineralization and plant nutrient demand. In: WOOMER, P. L. \& SWIFT, M. J., eds. The biological management of tropical soil fertility. New York, John Wiley \& Sons, 1994 p.81-116.

O'CONNELL, A.M. Nutrient dynamics in decomposing litter in karri (Eucalyptus diversicolor F. Muell.) forest of SouthWestern Australia. J. Ecol., 76:1186-1203, 1988.

PALM, C.A. Contribution of agroforestry trees to nutrient requirements of intercropped plants. Agrofor. Syst., 30:105-124, 1995.

PALM, C.A. \& SANCHEZ, P.A. Decomposition and nutrient release patterns of the leaves of three tropical legumes. Biotropica, 22:330-338, 1990.

PALM, C.A. \& SANCHEZ, P.A. Nitrogen release from the leaves of some tropical legumes as effected by their lignin and polyphenolic contents. Soil Biol. Biochem., 23:83-88, 1991.

PALM, C.A.; GACHENGO, C.N.; DELVE, R.J.; CADISCH, G. \& GILLER, K.E. Organic inputs for soil fertility management in tropical agroecosystems: Application of an organic resource database. Agriculture, Ecosyst. Environ., 83:27-42, 2001.

REINERSTSEN, S.A.; ELLIOT, L.F.; COCHRAN, V.L. \& CAMPBELL, G.S. "Role of available carbon and nitrogen in determining the rate of wheat straw decomposition." Soil Biol. Biochem., 16:459-464, 1984.
SANCHEZ, P.A. Properties and management of soils in the tropics. New York, W-I Publication, 1976. 630p.

SCHLESINGER, W.H. Biogeochemistry: An analysis of global change. San Diego, Academic Press, 1997. 588p.

SCHLESINGER, W.H. \& HASEY, M.M. Decomposition of chaparal shrub foliage: Losses of organic and inorganic constituents from deciduous and evergreen leaves. Ecology, 62:762-774, 1981.

SENEVIRATNE, G. Litter quality and nitrogen release in tropical agriculture: Synthesis. Biol. Fert. Soils., 31:6064, 2000.

SINGH, B.B. \& JONES, J.P. Phosphorus sorption and desorption characteristics of soil as affected by organic residues. Soil Sci. Soc. Am. J., 40:389-394, 1976.

STEVEnSON, F.J. \& COLE, M.A. Cycles of soil: Carbon, nitrogen, phosphorus, sulfur, micronutrients. New York, Wiley, 1999. 427p.

SWIFT, M.J.; HEAL, O.W. \& ANDERSON, J.M. Decomposition in terrestrial ecosystems. Berkely, University of California Press, 1979. (Studies in Ecology, 5)

SWIFT, M.J.; RUSSELL-SMITH, A. \& PERFECT, T.J. Decomposition and mineral-nutrient dynamics of plant litter in a regenerating bush-fallow in sub-humid Tropical Nigeria. J. Ecol., 69:981-995, 1981.

THOMAS, R.J. \& ASAKAWA, N.M. Decomposition of leaf litter from tropical forage grasses and legumes. Soil Biol. Biochem., 25:1351-1361, 1993.

TIAN, G.; KANG, B.T. \& BRUSSAARD, L. Biological effects of plant residues with contrasting chemical composition under humid tropical conditions - decomposition and nutrient release. Soil Biol. Biochem., 24:1051-1060, 1992.

TIEssen, H.; STEWART, J.W.B. \& COLE, C.V. Pathway transformation in soils of differing pedogenesis. Soil Sci. Soc. Am. J., 48:853-858, 1984.

TUKEY, H.B. The leaching of substances from plants. Ann. Rev. Plant Physiol., 21:305-324, 1970.

VALLIS, I. \& JONES, R.J. Net mineralization of nitrogen in leaves and leaf litter of Desmodium intortum and Phaseolus atropurpureus mixed with soil. Soil Biol. Biochem., 5:391-398, 1973.

van SOEST, P.J. \& WINE, R.H. Determination of lignin and cellulose in acid-detergent fiber with permanganate. J. Assoc. Offic. Analyt. Chem., 51:780-785, 1968.

VITOUSEK, P.M.; TURNER, D.R.; PARTON, W.J. \& SANFORD, P.R. Litter decomposition on the Mauna Loa Environmental Matrix, Hawaii: Patterns, mechanisms, and models. Ecology, 75:418-429, 1994.

VOGT, K.A.; GRIER, C.C. \& VOGT, D.J. Production, turnover, and nutrient dynamics of above-and below ground detritus of world forests. Adv. Ecol. Res., 15:303-377, 1986.

WIDER, K.R. \& LANG, G.E. A critique of the analytical methods used in examining decomposition data obtained from litter bags. Ecology, 63:1636-1642, 1982. 
WOOD, T.; BORMANN, F.H. \& VOIGT, G.K. Phosphorus cycling in a Northern hardwood forest: Biological and chemical control. Science, 223:391-393, 1984.
YANAI, R.D. Phosphorus budget of a 70-year-old northern hardwood forest. Biogeochemistry, 17:179-207, 1992. 